\title{
ANALISA DAN EVALUASI UNTUK PENGEMBANGAN FITUR APLIKASI XYZ (SEBUAH PENDEKATAN STUDI KASUS)
}

\author{
Sudiana ${ }^{1}$, Ratna Sari ${ }^{2}$, Alwin Ponco Nugroho ${ }^{3}$, Muhammad Alif Ridho ${ }^{4}$, Timotius Christian Prawira ${ }^{5}$ \\ 1,2,3,4,5 Program Studi Sistem Informasi, Universitas Bina Nusantara, Jakarta Indonesia \\ E-mail: ${ }^{1}$ sudiana@ binus.edu, ${ }^{2}$ rasari@binus.edu, ${ }^{3}$ anugroho@binus.edu, ${ }^{4}$ mridho@ binus.edu, ${ }^{5}$ tprawira@ binus.edu
}

Submission date: 2020-02-19

Accepted date: $2020-02-25$

\begin{abstract}
The development of technology has now become the business artery of every company, which is not only just supporting the company's business processes but more than that is holding an important role in a company's business processes. So many Start Up popping up in Indonesia. Start Up in the current era is quite popular, many Start Ups overseas have successfully become a large company. PT. XYZ is a company engaged in services to help businesses, especially MSMEs. PT. XYZ provides an XYZ application which is a website-based application for invoicing, accounting \& inventory that is easy to use for all business owners, especially MSMEs. The problems that exist in PT. XYZ comes from the user when using the application, especially with features that are widely used by users, where access is given to all users no different from one user to another user, so the business owner cannot limit user access. The purpose of writing this paper is to analyze and evaluate the features of an XYZ application at PT. XYZ and develop features so that it makes it easier for customers to do invoicing, accounting, and inventory. Evaluation uses direct interview techniques to the user and analysis using the Unified Modeling Language (UML) diagram to visualize, design, and document the features of the XYZ application. The results of this paper are developing features such as, User Access Rights, Reminder via Email, Multi Location, Import \& Export Data, and Advanced Invoice Settings, where this development provides more service to customers to make it easier and more efficient when using the application XYZ
\end{abstract}

Keywords : StarUp, Evaluation, PT. XYZ, Website.

\begin{abstract}
ABSTRAK
Perkembangan teknologi saat ini sudah menjadi urat nadi bisnis setiap perusahaan, yang tidak saja hanya sekedar pendukung proses bisnis perusahaan tetapi lebih dari itu ialah memegang peranan penting dalam suatu proses bisnis perusahaan. Sehingga banyak bermunculan Start Up di indonesia. Start Up pada era sekarang cukup populer, banyak Start Up di luar negeri yang sukses menjadi sebuah perusahaan besar. PT. XYZ merupakan perusahaan yang bergerak dibidang jasa untuk membantu para pelaku usaha terutama UMKM. PT. XYZ menyediakan sebuah aplikasi XYZ yang merupakan aplikasi berbasis website untuk invoicing, accounting, \& inventory yang mudah digunakan oleh seluruh pemilik usaha terutama UMKM. Permasalahan yang ada pada PT. XYZ berasal dari user saat menggunakan aplikasi tersebut, terutama dengan fitur yang banyak digunakan oleh user, dimana akses yang diberikan kepada seluruh user tidak ada yang berbeda dari user satu dengan user lain, sehingga sang pemilik usaha tidak bisa membatasi akses user. Tujuan dari penulisan paper ini adalah untuk menganalisa dan mengevaluasi fitur pada sebuah aplikasi XYZ di PT.XYZ serta melakukan pengembangan fitur sehingga lebih memudahkan customer dalam melakukan invoicing, accounting, dan inventory. Evaluasi menggunakan teknik wawancara langsung kepada user dan analisa menggunakan Diagram Unified Modeling Language (UML) untuk memvisualisasi, merancang, dan mendokumentasikan fitur-fitur pada aplikasi XYZ. Hasil dari penulisan paper ini adalah melakukan pengembangan fitur seperti, Hak Akses User, Reminder via Email, Multi Location, Import \& Export Data, dan Advance Invoice Setting, dimana pengembangan ini memberikan pelayana lebih kepada customer agar menjadi lebih mudah dan efisien pada saat menggunakan aplikasi XYZ.
\end{abstract}

Kata Kunci: StarUp, Evaluasi, PT. XYZ, Website. 


\section{PENDAHULUAN}

Perkembangan teknologi saat ini sudah menjadi urat nadi bisnis setiap perusahaan, yang tidak saja hanya sekedar pendukung proses bisnis perusahaan tetapi lebih dari itu ialah memegang peranan penting dalam suatu proses bisnis perusahaan. Sehingga banyak bermunculan Start $U p$ di indonesia. Start Up pada era sekarang cukup populer, banyak Start $U p$ di luar negeri yang sukses menjadi sebuah perusahaan besar. PT. XYZ merupakan perusahaan yang bergerak dibidang jasa untuk membantu para pelaku usaha terutama UMKM. PT. XYZ menyediakan sebuah aplikasi XYZ yang merupakan aplikasi berbasis website untuk invoicing, accounting, \& inventory yang mudah digunakan oleh seluruh pemilik usaha terutama UMKM. Ketiga modul tersebut terintegrasi, sehingga memudahkan pemilik usaha untuk mengatur usaha mereka.

Aplikasi XYZ menggunakan SaaS untuk mempermudah serta mempercepat kinerja atau pelayanan supporting dan updating. Dengan pendekatan SaaS aplikasi tidak memerlukan banyak interaksi dengan antarmuka lain serta memiliki kegunaan yang simple. Dengan menggunakan keuntungan dari SaaS ini adalah konsumen tidak perlu membeli lisensi software lagi, tinggal berlangganan ke provider cloud dan tinggal membayar berdasarkan pemakaian (Alex Budiyanto 2012). Pada dasarnya Penerapan teknologi dalam sistem informasi perusahaan hendaknya mempertimbangkan pemakai sistem sehingga teknologi yang diterapkan dapat bermanfaat sesuai dengan tugas dan kemampuan pemakai (Jumaili 2011). Sehingga penulis melakukan observasi yang dilakukan terkait aplikasi XYZ penulis menemukan masalah yang muncul berasal dari user saat menggunakan aplikasi tersebut, terutama dengan fitur yang banyak digunakan oleh user, dimana akses yang diberikan kepada seluruh user tidak ada yang berbeda dari user satu dengan user lain, sehingga sang pemilik usaha tidak bisa membatasi akses user. Terdapat fitur fitur seperti adanya Order, Invoice.

Sistem adalah suatu rangkaian yang terdiri dari dua atau lebih komponen yang saling berhubungan dan saling berinteraksi satu sama lain untuk mencapai tujuan di mana sistem biasanya terbagi dalam sub sistem yang lebih kecil yang mendukung sistem yang lebih besar. (Romney, 2015). Sistem merupakan perangkat elemen yang saling bergantung yang bersama-sama mencapai tujuan tertentu. Dimana sistem harus memiliki organisasi, hubungan timbal balik, integrase dan tujuan pokok. (Gelinas, 2012) Berdasarkan kedua pengertian di atas, maka dapat disimpulkan bahwa pengertian sebuah sistem yaitu sekumpulan elemen atau komponen yang saling berhubungan atau terintegrasi yang berguna dalam mencapai suatu tujuan.

Web based Application adalah suatu sistem yang berkaitan dengan dokumen sebagai media untuk menampilkan teks, gambar, multimedia, dan lainnya pada jaringan internet (Sibero 2011). Pengertian lain menyebutkan keseluruhan halaman-halaman web yang terdapat dalam sebuah domain yang mengandung informasi (Hidayat 2010). Dengan demikian, dapat disimpulkan bahwa Web based Application adalah suatu halaman web yang langsung terhubung menggunakan internet dimana di dalamnya terdapat berbagai macam informasi dalam bentuk teks, gambar, multimedia, dan lainnnya.

Didalam model Software as a Service (SaaS), para customer hanya menggunakan aplikasi - aplikasi yang disediakan oleh cloud infrastructure. Khususnya, seperti aplikasi aplikasi tersebut yang termasuk dalam layanan email berbasis web (Google's Gmail) dan rangkaian produktivitas berbasis web (seperti Zoho atau Google Docs), tapi juga aplikasi lanjutan seperti sistem CRM, sebagaimana disediakan oleh salesforce.com. Khususnya, pelanggan hanya peduli tentang aplikasinya, tanpa pengetahuan atau control atas infrastruktur yang mendasarinya, dan biasanya hanya memiliki kemampuan terbatas untuk mengontrol Payment, dan masih terdapat banyak bug di setiap fitur fitur yang terdapat di software SaaS (Software as a Service). Sebagai contoh ketika user bagian Sales bisa membuat invoice dan mengirim kepada customer dimana seharusnya tugas tersebut merupakan kewajiban dan tanggung jawab dari bagian accounting. Selain itu akses tanpa batas juga dimiliki oleh bagian Sales termasuk create journal, release dan posting.

Berdasarkan hal tersebut, penulis melakukan Analisa menyeluruh terkait aplikasi XYZ dimana selanjutnya akan melakukan pengembangan fitur pada aplikasi XYZ sesuai dengan kebutuhan suatu perusahaan.

Sistem adalah suatu rangkaian yang terdiri dari dua atau lebih komponen yang saling berhubungan dan saling berinteraksi satu sama lain untuk mencapai tujuan di mana sistem biasanya terbagi dalam sub sistem yang lebih kecil yang mendukung sistem yang lebih besar (Romney 2013). Sistem merupakan perangkat elemen yang saling bergantung yang bersama-sama mencapai tujuan tertentu. Dimana sistem harus memiliki organisasi, hubungan timbal balik, integrase dan tujuan pokok (Gelinas 2012). Berdasarkan kedua pengertian di atas, maka dapat disimpulkan bahwa pengertian sebuah sistem yaitu sekumpulan elemen atau komponen yang saling berhubungan atau terintegrasi yang berguna dalam mencapai suatu tujuan.

Web based Application adalah suatu sistem yang berkaitan dengan dokumen sebagai media untuk menampilkan teks, gambar, 
multimedia, dan lainnya pada jaringan internet (Sibero 2011). Pengertian lain menyebutkan keseluruhan halaman-halaman web yang terdapat dalam sebuah domain yang mengandung informasi (Hidayat 2010). Dengan demikian, dapat disimpulkan bahwa Web based Application adalah suatu halaman web yang langsung terhubung menggunakan internet dimana di dalamnya terdapat berbagai macam informasi dalam bentuk teks, gambar, multimedia, dan lainnnya.

Di dalam model Software as a Service (SaaS), para customer hanya menggunakan aplikasi - aplikasi yang disediakan oleh cloud infrastructure. Khususnya, seperti aplikasi aplikasi tersebut yang termasuk dalam layanan email berbasis web (contoh, Google's Gmail) dan rangkaian produktivitas berbasis web (seperti Zoho atau Google Docs), tapi juga aplikasi lanjutan seperti sistem CRM, sebagaimana disediakan oleh salesforce.com. Khususnya, pelanggan hanya peduli tentang aplikasinya, tanpa pengetahuan atau control atas infrastruktur yang mendasarinya, dan biasanya hanya memiliki kemampuan terbatas untuk mengontrol atau mengkonfigurasi pengaturan khusus aplikasi. Aplikasi berbasis model SaaS biasanya lebih mudah untuk deploy, karena pelanggan tidak harus mengkhawatirkan tentang maintenance atau update terhadap aplikasi, platform dasar, atau infrastruktur hardware (S.Valacich, J., \& Schneider 2014).

\section{METODE PENELITIAN}

Pengembangan fitur yang akan dilakukan nantinya direncanakan ke dalam tahapan langkah langkah secara sistematis, yaitu:

\section{Evaluasi}

Tahapan ini bertujuan untuk memeriksa hasil data dari wawancara user dan founder aplikasi PT. XYZ. Proses evaluasi dilakukan dengan melakukan wawancara terhadap user pengguna aplikasi PT. XYZ secara bertemu langsung.

2. Observasi

Pengamatan atau observasi adalah teknik pengumpulan data dimana peneliti mengumpulkan data dengan mengamati secara langsung pada kejadian atau proses di lapangan. Sugiyono. (2015). Jenis informasi yang diperoleh dapat berupa karakteristik benda, proses interaksi benda, atau perilaku manusia baik interaksinya dengan benda/alat maupun interaksinya dengan manusia lain. Kami melakukan observasi terhadap aplikasi XYZ dengan cara menggunakan aplikasi tersebut untuk mengetahui proses bisnis dan alur proses dari setiap modul.

\section{Analisa dan Perancangan}

Metode analisa dan perancangan yang digunakan adalah UML “Unified Modelling
Language" yaitu suatu metode permodelan secara visual untuk sarana perancangan sistem berorientasi objek, atau definisi UML yaitu sebagai suatu bahasa yang sudah menjadi standar pada visualisasi, perancangan dan juga pendokumentasian sistem software. UML yang digunakan adalah Use Case Diagram, Use Case Description, Class Diagram, Sequence Diagram, dan Multi Layer Diagram.

Penulis membuat UML berdasarkan alur yang ada pada aplikasi XYZ dengan cara menganalisa dan menerjemahkan hasil analisa ke dalam bentuk salah satu UML yaitu Activity Diagram. Hasil dari masalah juga diterjemahkan ke dalam bentuk UML yaitu Actitivy Diagram, System Sequence Diagram, Class Diagram, Use Case Diagram, dan Use Case Description.

\section{HASIL DAN PEMBAHASAN}

\section{Analisis Masalah pada Sistem Berjalan}

Masalah - masalah yang dihadapi dari proses bisnis berjalan oleh Paper.Id Berdasarkan hasil dengan melakukan penjajakan langsung kepada pengguna Paper.Id dimana terdapat 6 segmentasi jenis usaha yaitu:

Travel

Beberapa masalah yang bisa di highlight adalah:

1. Aplikasi XYZ masih perlu melakukan perbaikan fungsi dalam sistem terkait contoh: Modul Finance, pada saat melakukan proses input data, dimana data sebelumnya sudah dihapus namun masih muncul dan menjadi auto release dan tidak bisa dihapus.

2. Perlunya dilakukan custom pengembangan fitur terkait kebutuhan di industri Travel yaitu: perlunya penambahan fitur nomor booking code, rute, dan kode pesawat di mana selama ini informasi tersebut ditampilkan di bagian demakalah.

3. Dibutuhkan pengembangan aplikasi via mobile apps yaitu $I o S$, karena cukup banyak pengguna yang lebih aktif menggunakan smartphone dibandingkan $P C$.

4. Secara keseluruhan aplikasi XYZ sudah memenuhi kebutuhan dari industri travel. Jasa

Beberapa masalah yang dihighlight adalah :

1. Dibutuhkan pengembangan aplikasi via IoS mobile apps, karena cukup banyak pengguna yang lebih aktif menggunakan smartphone dibandingkan $P C$.

2. Perlunya dilakukan custom untuk bagian diskon tidak hanya bentuk persen tapi juga ditambahkan versi rupiah.

\section{Kuliner}

Beberapa masalah yang dihighlight adalah :

1. Aplikasi XYZ masih membutuhkan pengembangan fitur yaitu : fitur export import excel, hampir seluruh customer dibidang 
Kuliner membutuhkan export dan import to excel.

2. Perlunya dilakukan pengembangan fitur terkait kebutuhan di industri Kuliner yaitu : fitur retur karena ada barang yang butuh untuk dikembalikan.

3. Secara keseluruhan aplikasi XYZ sudah memenuhi kebutuhan industri Kuliner.

Retail

Beberapa Masalah yang dihighlight adalah:

1. Perlunya di lakukan pengembangan fitur seputar multi location, karena banyak pengguna berjenis usaha Retail memiliki gudang yang berjumlah lebih dari satu. Sehingga untuk pengaturan dan laporan produk menjadi kurang detil

2. Perlunya pengembangan fungsi pada kolom sales person yang ada pada sales invoice dan sales order, karena sangat menyulitkan user untuk mencari sales person tersebut. Contoh : user memiliki 10 sales, sehingga dia harus mencari terlebih dahulu secara manual sales yang akan dipilihnya.

3. Dibutuhkan pengembangan aplikasi via $I o S$ mobile apps, karena cukup banyak pengguna yang lebih aktif menggunakan smartphone dibandingkan $P C$.

4. Dibutuhkan penambahan fitur seputar hak akses pengguna, untuk membatasi hak akses pada penggunanya karena di aplikasi XYZ memiliki fitur multi user. Fitur multi user kurang berguna tanpa adanya hak akses pengguna.

Kesehatan

Beberapa masalah yang di highlight adalah :

1. Aplikasi XYZ masih harus memberikan beberapa background yang berwarna di tampilan Invoice sehingga terlihat lebih menarik di mata customer

2. Aplikasi XYZ membutuhkan pengembangan aplikasi mobile pada system IoS karena beberapa customer menggunakan handphone berbasis $I o S$ tidak hanya android saja.

\section{Logistik}

Beberapa masalah yang di highlight adalah :

1. Aplikasi XYZ membutuhkan pengembangan system di bagian Invoice agar systemnya dapat berjalan secara otomatis dalam mengirimkan tagihan ke customer setiap 3 hari atau tiap 1 minggu, sehingga customer tidak kerepotan dalam menagih dan lupa dalam melakukan pembayaran.

2. Aplikasi XYZ membutuhkan pengembangan system di bagian laporan keuangan dan tagihan dalam melakukan pengecekan secara otomatis dan menanmbah list baru untuk tagihan yang sudah dibayar dan tagihan yang belum dibayar.

3. Aplikasi XYZ membutuhkan pengembangan system di bagian tracking sehingga customer dalam melacak jejak kirimannya tidak hanya lewat marketplace tapi juga bisa menggunakan platform social media seperti facebook atau instagram.

4. Aplikasi XYZ membutuhkan pengembangan system dalam melakukan attachment dokumen lain di applikasi whatsapp, dikarenakan user menggunakan aplikasi lain dalam melihat list pengiriman barang customer.

\section{Solusi Permasalahan}

Berdasarkan masalah - masalah yang telah diidentifikasi sebelumnya, berikut adalah usulan untuk pemecahan masalah tersebut dimana penulis mengusulkan untuk melakukan pengembangan fitur yaitu:

1. Penambahan Fitur Hak Akses User Penambahan fitur hak akses user dimaksudkan untuk mengakomodir masalah yang telah dianalisa dan dikembangkan.Hak akses user pada aplikasi XYZ terbagi menjadi tiga, yaitu owner, admin, dan marketing. Setiap user memiliki akses yang berbeda-beda.

2. Penambahan Fitur Reminder Via Email Penambahan fitur reminder via email dimaksudkan untuk mengakomodir masalah yang telah dianalisa dan dikembangkan dari permasalahan yang sudah disebutkan sebelumnya.

3. Penambahan Fitur Setting Discount Invoice Penambahan fitur setting discount invoice dimaksudkan untuk memudahkan pengaturan diskon terkait penjualan yang selama ini masih dilakukan manual.

4. Penambahan Fitur Export File Stok Penambahan fitur export file dimaksudkan untuk memudahkan create report dalam bentuk ms. excel ataupun pdf.

5. Penambahan Fitur Multi Location

Penambahan fitur multi location dimaksudkan untuk memudahkan user dalam pembuatan multi location.

Analisa dan Perancangan Penambahan Fitur Aplikasi XYZ

\section{Use Case Diagram}

Berikut hasil Use Case Diagram terhadap pengembangan aplikasi XYZ:

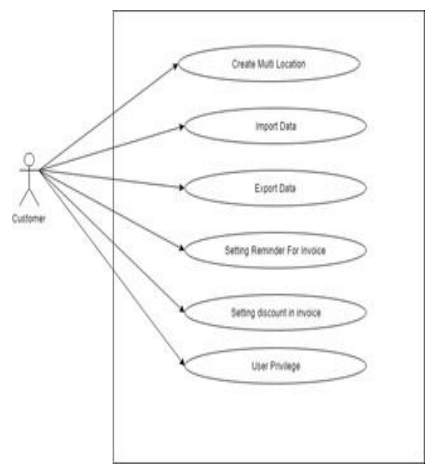

Sumber : (Sudiana, Ratna Sari, Alwin Ponco Nugroho, Muhammad Alif Ridho 2019)

Gambar 1. Use Case Diagram Pengembangan Aplikasi $\mathrm{XYZ}$ 


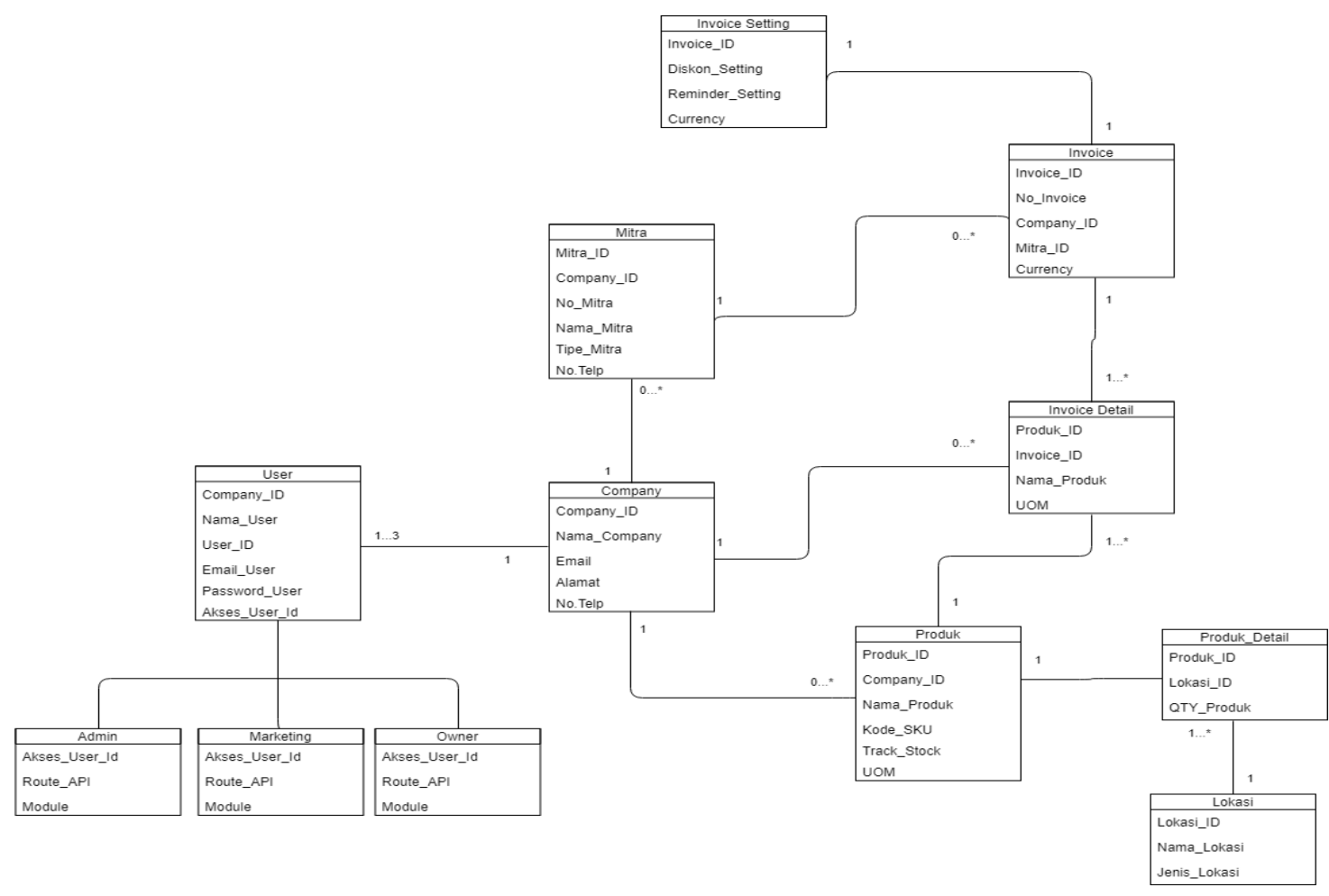

Sumber : (Sudiana, Ratna Sari, Alwin Ponco Nugroho, Muhammad Alif Ridho 2019)

Gambar 2. Class Diagram Pengembangan Aplikasi XYZ

\section{KESIMPULAN}

Berdasarkan hasil dari obersvasi serta analisa dan pengembangan yang dilakukan untuk aplikasi XYZ maka dapat disimpulkan sebagai berikut:

Terdapat enam segmentasi jenis usaha yang menggunakan aplikasi XYZ sebagai salah satu software pembantu untuk usaha mereka. Dan di setiap segmentasi tersebut memiliki berbagai macam kendala dalam menggunakan aplikasi XYZ. Enam segmentasi jenis usaha tersebut adalah Kuliner, Retail,Kesehatan, Tour and Travel, Logistik, dan Jasa.

Observasi dan wawancara dilakukan dimana ditemukan kendala dan akan dilakukan dalam bentuk pengembangan dan penambahan fitur. Terdapat tiga pengembangan fitur dan dua penambahan fitur. Dua pengembangan fitur tersebut adalah pengingat invoice untuk pengiriman email, mengatur jenis diskon di dalam invoice, dan multi-location. Dan untuk penambahan fitur adalah Import dan Export data dalam bentuk Excel, dan Hak akses pengguna.

\section{DAFTAR PUSTAKA}

Alex Budiyanto, I. L. 2012. "Pengantar Cloud Computing."

Gelinas, J. D. 2012. Accounting Information Systems. South Western: Cengage Learning. Hidayat, R. 2010. Cara Praktis Membangun Website Gratis. jakarta: PT Elex Media Komputindo.

Jumaili, S. 2011. "Kepercayaan Terhadap Teknologi Sistem Informasi Baru Dalam Evaluasi Kinerja Individual." Simposium Nasional Akuntansi 722-735.

Romney, M. B. 2013. Accounting Information Systems. England: Pearson Educational Limited.

S.Valacich, J., \& Schneider, C. 2014. Information Systems Today. 7th ed. Washington DC: Pearson Education Limited.

Sibero, A. F. 2011. Kitab Suci Web Programing. Yogjakarta: MediaKom.

Sudiana, Ratna Sari, Alwin Ponco Nugroho, Muhammad Alif Ridho, Timotius Christian Prawira. 2019. ANALISA DAN EVALUASI UNTUK PENGEMBANGAN FITUR APLIKASI XYZ. jakarta. 
